\title{
THE DEVELOPMENT OF ISLAMIC COMMUNITY PARTICIPATION FOR EDUCATION SERVICES IN THE UNDERDEVELOPED REGIONS
}

\author{
Suroso \\ The Board of Local Development Planning, Pati Regency \\ Email: surosopati321@gmail.com
}

\begin{abstract}
Disparity of regional development has taken place everywhere. This study aimed to analyze underdeveloped regions and the development participation of the Islamic community for education services in the areas. This research was conducted in Pati Regency, employing a descriptive-quantitative approach. The data consisted of primary and secondary ones. It used descriptive analysis. The results showed that under-developed regions were located in the border regions (Sukolilo, Tlogowungu, and Jaken). Islamic society had significant roles in education services. Islamic civilization had essential functions for elementary school services with a participation rate of $30.9 \%$ in Sukolilo, 33.33\% in Togowungu, and 13.33\% in Jaken. Islamic society had greater junior high school services with a participation rate of 58.33\% in Sukolilo, 83,33\% in Tlogowungu, and $40 \%$ in Jaken. Islamic civilization has dominant secondary education services with a participation rate of $100 \%$ in Sukolilo, $80 \%$ in Tlogowungu, and 100\% in Jaken.
\end{abstract}

Abstrak: Kesenjangan pembangunan antar kawasan terjadi di berbagai tempat. Studi ini memiliki tujuan menganalisa pembangunan kawasan tertinggal dan partisipasi masyarakat Islam dalam pelayanan pendidikan di kawasan tersebut. Penelitian ini dilaksanakan di Kabupaten Pati. Penelitian ini menggunakan pendekatan deskriptifkuantitatif. Penelitian ini menggunakan data primer dan data sekunder. Teknik analisa data menggunakan analisis deskriptif. Hasil penelitian menunjukkan bahwa kawasan tertinggal berada di kawasan pinggiran (Sukolilo, Tlogowungu dan Jaken). Masyarakat Islam memiliki peran besar dalam pelayanan pendidikan di kawasan tertinggal. Masyarakat Islam memiliki peran dalam pelayanan SD/MI dengan tingkat partisipasi 30,9 \% di Sukolilo, 33,33\% di Tlogowungu dan 13, 33\% di Jaken. Masyarakat Islam memiliki peran lebih besar dalam pelayanan SMP/MTs dengan tingkat partisipasi 58,33\% di Sukolilo, 83, 33\% di Tlogowungu dan $40 \%$ di Jaken. Masyarakat Islam memiliki peran dominan dalam pelayanan pendidikan menengah dengan tingkat partisipasi $100 \%$ di Sukolilo, $80 \%$ di Tlogowungu dan 100\% di Jaken. 
Keywords: education service; Islamic community; participation; underdeveloped region

\section{INTRODUCTION}

Development is intended to realize equal and sustainable prosperity for the community in rural and urban areas. However, it is reality; different progress and disparity in effect have taken place everywhere. Suburban areas or border regions often have slow progress in development compared to urban areas. The areas which have slow progress in development are primarily located in the border regions. Those areas in the border regions are identified as rural areas, suburban areas, under-developed regions, poor regions, which tend to be marginalized. ${ }^{1}$

Most border regions have difficult accessibility because of the limited development of infrastructure. The problematic accessibility and mobility have impacts on getting social services. ${ }^{2}$ Other impacts of difficult accessibility are the problems of the economic activity of the community. They have barriers in marketing their products, so vulnerable poverty will come up. ${ }^{3}$ The community has obstacles and difficulty overcoming their social and economic problems by themselves. ${ }^{4}$ That is the reason why the disparity in development among the regions can not be denied. The discrepancy may include the financial aspect and social one. ${ }^{5}$ The comparative development often presumes a part of regions considered as under-developed regions. They can be analyzed from various perspectives, such as the economy, social, and environment.

Pati Regency has 21 districts, and the underdeveloped districts are identified in the suburban areas or border regions. Those regions have difficult accessibility of transportation. It has impacts on economic development and also social services, including education services in the areas. Therefore, the underdeveloped regions can be viewed from the perspectives of economy, social, and environment.

1 Aziz Budianta, "Pengembangan Wilayah Perbatasan Sebagai Upaya Pemerataan Pembangunan Wilayah Di Indonesia,” SMARTek 8, no. 1 (2010): 72-82.

2 Muhammad Atiullah Saif, Mohammad Maghrour Zefreh, and Adam Torok, "Public Transport Accessibility: A Literature Review," Periodica Polytechnica Transportation Engineering 47, no. 1 (2019): 36-43.

3 Pramod K. Singh and Harpalsinh Chudasama, "Evaluating Poverty Alleviation Strategies in a Developing Country,” PloS One 15, no. 1 (2020): e0227176.

${ }^{4}$ Qerim Qerimi and Bruno S. Sergi, "Development and Social Development in the Global Context," International Journal of Business and Globalisation 14, no. 4 (2015): 383-407.

5 Abubakar Hamzah, Raja Masbar, and Sofyan Syahnur, "Economic Growth Disparity among the Regions in Aceh, Indonesia," Aceh International Journal of Social Science 2, no. 1 (2013): 21-31. 
Relevant to the perspective, this study analyzed underdeveloped regions based on development village indexes (Index Desa Membangun/IDM) which include development achievement in three aspects, namely: economy, social, and environment. Hence, the more villages having status as underdeveloped ones in any region (district), are higher potential of the district falling to be an underdeveloped region.

Underdeveloped regions in this study are measured using the proportion rate of underdeveloped villages in any area (district). The definition of "underdeveloped village" is a village with a development village index (IDM) of more than 0.491 and less than 0.599. Development village index (IDM) is the average of three sub-indexes, including (a) social resilience index, (b) economic resilience index, and (c) environmental resilience index. ${ }^{6}$ Village development process and regional one need social capital. It is a strong social interaction among villagers or people in the region. It may increase adaptation capacity. ${ }^{7}$ It means that community participation is crucial in conducting development. Therefore, regional development becomes the responsibility of stakeholders, including the government and the community. In this study, community participation is restricted to "development participation of Islamic community for education services in underdeveloped regions," especially formal education services of primary education and secondary education (middle education).

This study aims (1) to analyze the development of underdeveloped regions based on the development village index (IDM) in the study area; and (2) to analyze Islamic community participation in education service development in the underdeveloped regions. Islamic community participation in education service development refers to the community having an Islamic organization with activities in education services proven with the existing formal schools in the study area.

\section{RESEARCH METHOD}

This research was conducted in Pati Regency. It employed a descriptivequantitative approach. It used primary and secondary data. The secondary data were collected by observing related documents. The primary data were collected by interviewing stakeholders related to education services. The analysis used a descriptive one. The analysis of underdeveloped regions is measured using the proportion rate of underdeveloped villages compared to other areas of the study area.

6 Permendes PDTT Nomor 2 Tahun 2016 Tentang Indeks Desa Membangun (Jakarta: Kemendes, 2016).

7 Ayu Kusumastuti, "Modal Sosial Dan Mekanisme Adaptasi Masyarakat Pedesaan Dalam Pengelolaan Dan Pembangunan Infrastruktur,” MASYARAKAT: Jurnal Sosiologi, 2015, 81-97. 
Criteria of "underdeveloped villages" are the villages that have development village indexes (IDM) more than 0.491 and less than 0.599 . Development village index (IDM) is the average of composite indexes consisting: (a) social resilience index (IKS); (b) economic resilience index (IKE); and (c) environmental resilience index (IKL).

$$
\mathrm{IDM}=(\mathrm{IKS}+\mathrm{IKE}+\mathrm{IKL}) / 3
$$

\section{THEORETICAL FRAMEWORK}

\section{Community Participation}

Community participation refers to community roles in the education services of formal schools. Community means a non-government institution that takes part in conducting education service. Participation implies the involvement of an individual or group in any activity. Therefore community participation means direct participation of the community in the process of development. ${ }^{8}$ Community participation in development has been mentioned in the law and regulation. Community participation in partnership among stakeholders, including government, private enterprise, and community, in the "PublicPrivate Partnership." The most important thing needed to achieve the concept is empowerment community in the development. ${ }^{9}$ Community participation is influenced by some factors such as personal interest, education, social, and economy. ${ }^{10}$

Development becomes responsible stakeholders, including government and community. Therefore, technical performance in development is essential, and other crucial aspects are managing the community, transparency, accountability, and sustainability. Consequently, the better managing community is the higher potential of community participation in development. ${ }^{11}$ When development is conducted by the local community, using their ways and benefits, it can reduce urbanization and stimulate development progress which is useful for the community and the region. ${ }^{12}$

8 Rahmawati Rahmawati, "Partisipasi Masyarakat Dalam Pelayanan Pendidikan Di SDN Cibeusi Dan SDN Jatinangor" (Jakarta, Fisipol Universitas Indonesia, 2011).

9 Andi Rosdianti Razak, "Peran Serta Masyarakat Dalam Pembangunan," Otoritas: Jurnal Ilmu Pemerintahan 3, no. 1 (2013): 10-15.

${ }^{10}$ Ellen Boeren, Ides Nicaise, and Herman Baert, "Theoretical Models of Participation in Adult Education: The Need for an Integrated Model," International Journal of Lifelong Education 29, no. 1 (2010): 45-61.

${ }^{11}$ Andi Asnuddin, "Pendekatan Partisipatif Dalam Pembangunan Proyek Infrastruktur Perdesaan Di Indonesia,” Smartek 8, no. 3 (2010): 170-82.

${ }^{12}$ Fernandes Simangunsong and Imelda Hutasoit, "Empirical Study on Implementation of Village Fund for Issue of Urbanization from West Java Province to State Capital of Jakarta," International Business Management 11, no. 5 (2017): 1058-1072. 


\section{Development of Underdeveloped Regions}

Development is the effort to increase living quality and prosperity for the community. It relates to the context of development management at all levels because every level will influence another level in terms of social, economic, or even politics. Therefore, it should be viewed as an inter-relationship among villages in the district and districts in the regency. ${ }^{13}$ From the public policy perspective, development needs 5 (five) inherent aspects to achieve equal prosperity for the community. They are (1) the state obeying the rule of law and human rights; (2) democratic government should regulate, protect and serve the society; (3) legal justice of law in terms of certainty, benefit, and protection; (4) Development directed to targets, material and non-material, physical and mental, and existing of awareness that natural resources are limited; and (5) community empowerment that is more genuine. ${ }^{14}$

Public policy will determine the achievement of development. However, one approach will be implemented in various ways depending on the local context. Hence, the achievement of development is different among regions because every region has different resources and barriers. Thus, previous studies stated that underdeveloped regions existed in suburban areas or border regions. Therefore, those regions tend to have slower progress in development compared to other regions. In addition, some factors are causing slow progress of development in the villages of the border region. They are (a) social and economic potentials that have not been identified yet comprehensively; (b) weak capacity in social and economic service in the border region to serve the population in the area; and (c) social and economic services have not been distributed equally. ${ }^{15}$

\section{Development of Education Services}

It has been described previously that community participation refers to participation in education services, mainly formal schools, including primary education and middle education. In other words, those education services being concerned are formal education. Based on the government regulation, "formal education" is education having a particular structure and grades, including; primary education, middle education, and higher education. ${ }^{16}$

Education development is critical to support human resource competitiveness. Related to it, Indonesia has less developed if it is compared to other countries

${ }^{13}$ Nurman, Strategi Pembangunan Daerah (Jakarta: PT. Raja Grafindo Persada, 2015).

${ }^{14}$ Asep Warlan Yusuf, "Partisipasi Masyarakat Dalam Pembangunan Kota Yang Berkelanjutan Dan Berkeadilan,” Jurnal Administrasi Publik 11, no. 2 (2014): 53-68.

${ }^{15}$ Budianta, "Pengembangan Wilayah Perbatasan Sebagai Upaya Pemerataan Pembangunan Wilayah Di Indonesia."

16 "PP Nomor 13 Tahun 2015 Tentang Perubahan Kedua PP Nomor 19 Tahun 2005 Tentang Standar Nasional Pendidikan” (Jakarta: Kemendiknas, n.d.). 
in the world. The Global Competitiveness Report 2011-2012 made by World Economic Forum (WEF) stated that Indonesia was in 46 of 142 countries globally. Compared to ASEAN countries, Indonesian competitiveness was in position four after Singapore, Malaysia, and Thailand. ${ }^{17}$

Indonesian human resource competitiveness also was stated by United Nations Development Programme (UNDP) in 2012. Human Development Index (HDI) in Indonesia was ranked 124 in 184 countries. It consisted of three components of development. They were education, economy, and health. The Human Development Index (HDI) referred to education development and human resource quality. Position 124 is included in the category "low human development." ${ }^{18}$

Dealing with the Human Development Index (HDI), Indonesia has serious effort to develop middle education and vocational education using four strategies. Firstly, increasing quality and relevance of vocational secondary education, vocational higher education. Secondly, skill training relevant to the development needs, including graduation being ready to work, and having entrepreneurial skills, thirdly harmonizes and synergize vocational secondary education, vocational higher education, and skill training. Fourthly, strengthening intermediation and expanding opportunities. It is for an apprenticeship and harmonizing education and training with the world of work. Finally, secondary education development is critical to increasing human resource competitiveness. ${ }^{19}$

Education development becomes the responsibility of stakeholders, including the community. The characteristics of education services managed by the Islamic community generally have an effort to strengthen Islamic values and personal character. For example, schools in Madrasah (religious schools) are built based on Islamic values and essential characters. ${ }^{20}$

Recently, the development of the post transnationalism paradigm has influenced Islamic education in Indonesia. It promotes moderation values that exist in the multicultural community. ${ }^{21}$ Regarding national multiculturalism,

${ }^{17}$ U. S. Supardi, "Arah Pendidikan Di Indonesia Dalam Tataran Kebijakan Dan Implementasi," Formatif: Jurnal Ilmiah Pendidikan MIPA 2, no. 2 (2015): 111-21.

${ }^{18}$ DIRKA MEI OKPRINA, "Strategi Komunikasi Pengawas Pendidikan Menengah Di Lingkup Dinas Pendidikan Kabupaten Gresik," Inspirasi Manajemen Pendidikan 4, no. 4 (2014): 108-21.

${ }^{19}$ Nina, "Rancang Bangun Peningkatan Daya Saing SDM Indonesia," Info Kajian Bappenas Volume 8, Nomor 2, 2011, 1-5.

${ }^{20}$ Mukhibat, Muhammad Fahim Tharaba, and Munair Yusaf Abdalhafiz Salah, "The Management of IAIN Ponorogo-Assisted Madrasas: Religious, Populist, Center of Excellence, Diversity," Cendekia: Jurnal Kependidikan Dan Kemasyarakatan 18, no. 2 (2020): 171-187.

${ }^{21}$ Muhammad Thoyib, "The Management of Multicultural Resolution on PostTransnationalism of Indonesian Islamic Education: Challenges for the Future," Cendekia: Jurnal Kependidikan Dan Kemasyarakatan 18, no. 2 (2020): 231-247. 
understanding Islam should include history to integrate Islamic values in the social context of society. ${ }^{22}$ Balanced insights of Islamic values and social culture will be helpful to shape characters for educational output. Students begin to apply textures based on Islamic values and local wisdom in their lives. ${ }^{23}$ Strengthening characters in education can be mostly practiced in schools based on golden habits. ${ }^{24}$ The ways to shape characters in schools can be done by reconstructing educational, scientific books and prophetic values to shape civilized, educated, and well-behaved people. ${ }^{25}$

\section{RESEARCH FINDINGS AND DISCUSSION Development Based on IDM in Pati Regency}

Pati regency has 21 districts consisting of 401 villages. Development achievement based on IDM (development village index) in the regency shown the following results: (1) Villages having status as an independent village are 2 of 401 villages (0, $50 \%)$; (2) Villages having status as a developed village are 71 of 401 villages $(17,71 \%)$; (3) Villages having status as developing village are 313 of 401 villages $(78,05 \%)$, and (4) Villages having status as an underdeveloped village are 15 of 401 villages $(3,74 \%)$. The existence of development based on IDM in Pati Regency is shown in the following table.

Table 1. Existing of development based on IDM in Pati Regency

\begin{tabular}{|c|c|c|c|c|c|c|}
\hline \multirow[b]{2}{*}{ No } & \multirow[b]{2}{*}{ District } & \multirow[b]{2}{*}{ Villages } & \multicolumn{4}{|c|}{ Status of development based on IDM } \\
\hline & & & Independent & Developed & Developing & $\begin{array}{c}\text { Under- } \\
\text { developed }\end{array}$ \\
\hline 1 & Sukolilo & 16 & & 1 & 11 & $4(25,00 \%)$ \\
\hline 2 & Kayen & 17 & & 1 & 16 & \\
\hline 3 & Tambakromo & 18 & & 1 & 17 & \\
\hline 4 & Winong & 30 & & 3 & 27 & \\
\hline 5 & Pucakwangi & 20 & & 1 & 19 & \\
\hline 6 & Jaken & 21 & & 2 & 17 & $2(9,52 \%)$ \\
\hline 7 & Batangan & 18 & & 3 & 15 & \\
\hline 8 & Juwana & 29 & & 5 & 24 & \\
\hline
\end{tabular}

${ }^{22}$ Ivan Riyadi, "Manajemen Pendidikan Bermuatan Antropologi, Agama Dan Sosial," Cendekia: Jurnal Kependidikan Dan Kemasyarakatan 17, no. 2 (2019): 301-316.

${ }^{23}$ Iis Salsabilah, "Pendidikan Karakter Islami Berbasis Nilai-Nilai Kearifan Lokal (Penelitian Di SDN 12 Ciseureuh Kahuripan Pajajaran Purwakarta)," Cendekia: Jurnal Kependidikan Dan Kemasyarakatan 17, no. 2 (2019): 269-284.

${ }^{24}$ Arham Junaidi Firman and Nur Hidayat, "Strengthening Character Education Based on Golden Habits at SMP Muhammadiyah 1 Depok Yogyakarta," Cendekia: Jurnal Kependidikan Dan Kemasyarakatan 18, no. 2 (2020): 189-210.

${ }^{25}$ Ruslan Ruslan and Luthfiyah Luthfiyah, "Reconstruction of Educational Science With Prophetic Paradigm in Faculty of Tarbiyah at IAI Muhammadiyah Bima," Cendekia: Jurnal Kependidikan Dan Kemasyarakatan 18, no. 2 (2020): 291-311. 


\begin{tabular}{|c|c|c|c|c|c|c|}
\hline 9 & Jakenan & 23 & & 1 & 20 & $2(8,70 \%)$ \\
\hline 10 & Pati & 24 & 2 & 11 & 11 & \\
\hline 11 & Gabus & 24 & & 2 & 21 & $1(4,17 \%)$ \\
\hline 12 & Margorejo & 18 & & 5 & 13 & \\
\hline 13 & Gembong & 11 & & 0 & 10 & $1(9,09 \%)$ \\
\hline 14 & Tlogowungu & 15 & & 0 & 12 & $3(20,00 \%)$ \\
\hline 15 & Wedarijaksa & 18 & & 1 & 17 & \\
\hline 16 & Trangkil & 16 & & 14 & 2 & \\
\hline 17 & Margoyoso & 22 & & 7 & 13 & $2(9,09 \%)$ \\
\hline 18 & Gunungwungkal & 15 & & 0 & 15 & \\
\hline 19 & Cluwak & 13 & & 2 & 11 & \\
\hline 20 & Tayu & 21 & & 9 & 12 & \\
\hline \multirow[t]{2}{*}{21} & Dukuhseti & 12 & & 2 & 10 & \\
\hline & Pati Regency & 401 & 2 & 71 & 313 & $15(3,74 \%)$ \\
\hline
\end{tabular}

(Source: Dispermades Pati Regency, 2019)

Fifteen underdeveloped villages exist in 7 districts. Firstly, Sukolilo district has 16 villages and 4 of them having status as an underdeveloped village. The district is located in the southern border area. Secondly, Jaken district has 21 villages, and two of them having status as an underdeveloped village. The district is located in the eastern border area. Thirdly, Jakenan district has 23 villages and two of them having status as underdeveloped villages. This district is located in the southeastern suburban area. Fourthly, the Gabus district has 24 villages, and one of them having status as an underdeveloped village. It is located in a southern suburban area. Fifthly, Gembong district has 11 villages and one of them having a level as an underdeveloped village. The district is located in the western border area. Sixthly, the Tlogowungu district has 15 villages, and 3 have status as the underdeveloped village. The district is located in the northwest border area. Seventhly, Margoyoso district has 22 villages and two of them having a rate as the underdeveloped village. The district is located in a north suburban area.

\section{Underdeveloped Region Based on IDM}

Underdeveloped regions are measured using the proportion rate of underdeveloped villages. It is compared to other regions in the study area. Based on the data in table 1, three underdeveloped regions are Sukolilo district, Tlowungu district, and Jaken district. Firstly, Sukolilo district has the highest proportion of underdeveloped villages.

It is located in the southern border area. This district has 16 villages. Based on IDM, the district has one village with status as a developed village, 11 villages with level as developing village, and four villages having status as the 
underdeveloped village. It means that the proportion of underdeveloped villages is $25 \%$. Therefore, it becomes the first underdeveloped region.

Secondly, the Tlogowungu district became the second underdeveloped region in the study area. It is located in the northwest border area. Tlogowungu district has 15 villages. Dealing with development based on IDM, the district has 11 villages having status as developing village and three villages having status as the underdeveloped village. It means that the proportion of underdeveloped villages is $20 \%$. Therefore, this region becomes the second underdeveloped region. The existence of underdeveloped villages in three areas is shown in table 2.

Table 2. Development village indexes in underdeveloped regions

\begin{tabular}{lllcccc}
\hline \multirow{2}{*}{ No } & \multicolumn{2}{c}{ Underdeveloped Region } & \multicolumn{4}{c}{ Development Village Index } \\
& \multicolumn{1}{c}{ Village } & \multicolumn{1}{c}{ District } & IKS & IKE & IKL & IDM \\
\hline 1 & Prawoto & Sukolilo & 0,6571 & 0,5333 & 0,5333 & 0,5746 \\
2 & Pakem & Sukolilo & 0,6400 & 0,4667 & 0,5333 & 0,5467 \\
3 & Kuwawur & Sukolilo & 0,6286 & 0,5333 & 0,4667 & 0,5429 \\
4 & Porangparing & Sukolilo & 0,5771 & 0,4667 & 0,6000 & 0,5479 \\
5 & Suwatu & Tlogowungu & 0,6686 & 0,6500 & 0,4667 & 0,5951 \\
6 & Klumpit & Tlogowungu & 0,6343 & 0,6000 & 0,4667 & 0,5670 \\
7 & Gunungsari & Tlogowungu & 0,6571 & 0,6000 & 0,4667 & 0,5746 \\
8 & Kebonturi & Jaken & 0,6914 & 0,6000 & 0,4667 & 0,5860 \\
9 & Sumberarum & Jaken & 0,6229 & 0,4500 & 0,6667 & 0,5799 \\
\hline
\end{tabular}

(Source: Dispermades Pati Regency, 2019)

Thirdly, the Jaken district became the third underdeveloped region. It is located in the eastern border area. Jaken district has 21 villages. Related to the achievement of development based on IDM, the district has two villages with status as the developed village, 17 villages with status as developing villages, and two villages with status as the underdeveloped village. It means that the proportion of underdeveloped villages is $9.52 \%$. Therefore, this region becomes the third underdeveloped region. Cumulatively, the three underdeveloped areas have 9 of 15 underdeveloped villages (60\%).

\section{Community Participation in Education Service of Elementary Schools in Underdeveloped Regions}

The underdeveloped regions are the Sukolilo district, Tlogowungu district, and Jaken district. Before describing the community roles in the education service of elementary schools in underdeveloped regions, it will be previously described the existing elementary schools in Pati regency. It is intended for a general understanding of the education service of elementary schools (SD/MI) in the 
area study. Pati regency has 879 elementary schools (SD/MI) including: (a) 647 state elementary schools (SDN); (b) 31 private elementary schools (SDS); (c) 2 state MI (MIN); and (d) 199 private MI (MIS). The existence of elementary schools (SD/MI) in Pati regency is shown in table 3.

Tabel 3. Existing of elementary schools (SD/MI) in Pati regency

\begin{tabular}{|c|c|c|c|c|c|c|c|}
\hline \multirow{2}{*}{ No } & \multirow{2}{*}{ District } & \multicolumn{5}{|c|}{ Elementary schools (SD/MI) } & \multirow{2}{*}{$\begin{array}{l}\text { Islamic } \\
\text { Schools }\end{array}$} \\
\hline & & SDN & SDS & MIN & MIS & Total & \\
\hline 1 & Sukolilo & 38 & 2 & & 15 & 55 & $17(30,9 \%)$ \\
\hline 2 & Kayen & 38 & & 1 & 15 & 54 & \\
\hline 3 & Tambakromo & 32 & & & 2 & 34 & \\
\hline 4 & Winong & 40 & & & 11 & 51 & \\
\hline 5 & Pucakwangi & 27 & & & 11 & 38 & \\
\hline 6 & Jaken & 26 & & & 4 & 30 & $4(13,33 \%)$ \\
\hline 7 & Batangan & 23 & & & 5 & 28 & \\
\hline 8 & Juwana & 40 & 4 & & 4 & 48 & \\
\hline 9 & Jakenan & 27 & & & 6 & 33 & \\
\hline 10 & Pati & 51 & 10 & & 4 & 65 & \\
\hline 11 & Gabus & 36 & 1 & & 3 & 40 & \\
\hline 12 & Margorejo & 29 & 1 & & 3 & 33 & \\
\hline 13 & Gembong & 23 & & & 17 & 40 & \\
\hline 14 & Tlogowungu & 30 & 1 & & 14 & 45 & $15(33,33 \%)$ \\
\hline 15 & Wedarijaksa & 27 & & & 7 & 34 & \\
\hline 16 & Trangkil & 28 & 1 & & 9 & 38 & \\
\hline 17 & Margoyoso & 30 & 2 & & 20 & 52 & \\
\hline 18 & Gunungwungkal & 21 & & & 11 & 32 & \\
\hline 19 & Cluwak & 28 & & & 12 & 40 & \\
\hline 20 & Tayu & 28 & 8 & & 14 & 50 & \\
\hline \multirow[t]{2}{*}{21} & Dukuhseti & 25 & 1 & 1 & 19 & 46 & \\
\hline & Pati regency & 647 & 31 & 2 & 199 & 879 & \\
\hline
\end{tabular}

(Source: Education department in Pati regency, 2019)

Participation of the Islamic community has important roles in the education development of elementary schools (SD/MI) in underdeveloped regions. The first underdeveloped region is the Sukolilo district. Participation of the Islamic community in the education service of elementary schools (SD/MI) in this region is relatively great. Sukolilo district has 55 elementary schools (SD/ MI) including: (a) 33 state elementary schools (SDN); (b) 2 private elementary schools (SDS); (c) 15 private MI (MIS). There are 17 private elementary schools (SDS/MIS). According to the interviewees from the education department in Pati Regency, those 17 private elementary schools (SDS/MIS) are managed by 
the Islamic community (NU and Muhammadiyah). It means that Islamic society has important roles with participation rate for elementary schools $30.9 \%$ (17 of 55) in Sukolilo.

The second underdeveloped region is the Tlogowungu district. Participation of the Islamic community in the education service of elementary schools (SD/ $\mathrm{MI}$ ) in this region is greater. Tlogowungu district has 45 elementary schools (SD/ MI) including: (a) 30 state elementary schools (SDN); (b) 1 private elementary school (SDS); (c) 14 private MI (MIS). There are 15 private elementary schools (SDS/MIS). According to the interviewees from the education department in Pati Regency, those 15 private elementary schools (SDS/MIS) are managed by the Islamic community (NU and Muhammadiyah). It means that Islamic society has important roles with participation rate for elementary schools $33.33 \%$ (15 of 45) in Tlogowungu.

The third underdeveloped region is the Jaken district. Participation of the Islamic community in the education service of elementary schools (SD/MI) in this region is less great than before. Jaken district has 30 elementary schools (SD/MI) including: (a) 26 state elementary schools (SDN); and (b) 4 private MI (MIS). There are only four private elementary schools (MIS). According to the interviewees from the education department in Pati Regency, those four private elementary schools (SDS/MIS) are managed by the Islamic community (NU). Islamic society has fewer roles with a participation rate of primary school 13.33 $\%$ (4 of 30) in Jaken. This region has the least role in the education service of elementary schools (SDS/MIS) compared to another underdeveloped region.

\section{The Community Participation in Education Service of Junior High Schools in Underdeveloped Regions}

The underdeveloped regions are the Sukolilo district, Tlogowungu district, and Jaken district. Before describing the community participation in the education service of junior high schools in the underdeveloped areas, it will be previously described the existence of junior high schools in Pati regency. It is intended to comprehensively understand junior high schools (SMP/MTs) in the area study.

Pati regency has 224 junior high schools (SMP/MTs) including: (a) 58 state junior high schools (SMPN/Satap); (b) 26 private junior high schools (SMPS); (c) 3 State MTs (MTs N); and (d) 134 private MTs (MTs S). The existing education service for junior high schools (SMP/MTs) in Pati Regency is shown in the following table. 
Table 4. Existing of education service of junior high schools in Pati regency

\begin{tabular}{|c|c|c|c|c|c|c|c|}
\hline \multirow[b]{2}{*}{ No } & \multirow[b]{2}{*}{ District } & \multicolumn{5}{|c|}{ Junior high schools (SMP/MTs) } & \multirow{2}{*}{$\begin{array}{l}\text { Private } \\
\text { Islamic } \\
\text { Schools }\end{array}$} \\
\hline & & SMPN/Satap & SMPS & MTs N & MTs S & Total & \\
\hline 1 & Sukolilo & 5 & 3 & & 4 & 12 & $7(58,33 \%)$ \\
\hline 2 & Kayen & 3 & 5 & & 9 & 17 & \\
\hline 3 & Tambakromo & 5 & & & 4 & 9 & \\
\hline 4 & Winong & 2 & 1 & 1 & 4 & 8 & \\
\hline 5 & Pucakwangi & 4 & & & 8 & 12 & \\
\hline 6 & Jaken & 3 & & & 2 & 5 & $2(40 \%)$ \\
\hline 7 & Batangan & 2 & & & 3 & 5 & \\
\hline 8 & Juwana & 4 & 3 & & 3 & 10 & \\
\hline 9 & Jakenan & 2 & & & 3 & 5 & \\
\hline 10 & Pati & 8 & 4 & & 5 & 17 & \\
\hline 11 & Gabus & 2 & 1 & & 5 & 8 & \\
\hline 12 & Margorejo & 2 & 2 & & 3 & 7 & \\
\hline 13 & Gembong & 1 & 1 & 1 & 10 & 13 & \\
\hline 14 & Tlogowungu & 2 & & & 10 & 12 & $10(83,33 \%)$ \\
\hline 15 & Wedarijaksa & 2 & 2 & & 6 & 10 & \\
\hline 16 & Trangkil & 2 & & & 8 & 10 & \\
\hline 17 & Margoyoso & 3 & & 1 & 15 & 19 & \\
\hline 18 & Gunungwungkal & 2 & & & 5 & 7 & \\
\hline 19 & Cluwak & 1 & 1 & & 8 & 10 & \\
\hline 20 & Tayu & 2 & 3 & & 10 & 15 & \\
\hline \multirow[t]{2}{*}{21} & Dukuhseti & 2 & 2 & & 9 & 13 & \\
\hline & Pati regency & 59 & 28 & 3 & 134 & 224 & \\
\hline
\end{tabular}

(Source: Education department, Pati regency, 2019)

The participation of the Islamic community has important roles in the education development of junior high schools (SMP/MTs) in underdeveloped regions. The first underdeveloped region is the Sukolilo district. Participation of the Islamic community in the education service of junior high schools (SMP/ MTs) in this region is very great. Sukolilo district has 12 junior high schools (SMP/MTs) including: (a) 5 state junior high schools (SMPN /Satap); (b) 3 private junior high schools (SMPS); and (c) 4 private MTs (MTs S). There are seven private junior high schools (SMPS /MTs S) in this area. According to the interviewees from the education department in Pati Regency, those seven private junior high schools (SMPS /MTs S) are managed by the Islamic community (NU and Muhammadiyah). It means that Islamic society has great roles with participation rate for junior high schools (SMP/MTs) 58.33\% (7 of 12 schools) in Sukolilo district. 
The second underdeveloped region is the Tlogowungu district. Participation of the Islamic community in the education service of junior high schools (SMP/ MTs) in this region is very dominant. Tlogowungu district has 12 junior high schools (SMP/MTs) including: (a) 2 state junior high schools (SMPN /Satap); and (b) 10 private MTs (MTs S). There are ten private junior high schools (MTs S) in this area. According to the interviewees from the education department in Pati Regency, those ten private junior high schools (MTs S) are managed by the Islamic community (NU). Islamic society has very dominant roles with participation rate for junior high schools $83.33 \%$ (10 of 12 schools) in Tlogowungu district.

The third underdeveloped region is the Jaken district. Participation of the Islamic community in the education service of junior high schools (SMP/MTs) in this region is very dominant. Jaken district has 5 junior high schools (SMP/ MTs) including: (a) 3 state junior high schools (SMPN /Satap); and (b) 2 private MTs (MTs S). There are two private junior high schools (MTs S) in this area. According to the interviewees from the education department in Pati Regency, those two private junior high schools (MTs S) are managed by the Islamic community (NU). It means that Islamic society has good enough roles with participation rate for junior high schools $40 \%$ ( 2 of 5 schools) in Jaken district.

\section{The Community Participation in Education Service of Secondary Education in Underdeveloped Regions}

Secondary education (middle education) is formal education after primary education. The secondary education consists of senior high school (SMA), vocational secondary education (SMK), and Madrasah Aliyah (MA). The underdeveloped regions in the study area are Sukolilo district, Tlogowungu district, and Jaken district. Before describing the community participation in education service of secondary education in the underdeveloped regions, it will be explained integrated with the existence of secondary schools in Pati regency. It is intended for a comprehensive understanding of education service of secondary education in the area of study.

Pati regency has 135 schools of secondary education including: (a) 8 state senior high school (SMAN); (b) 17 private senior high school (SMAS); (c) 6 state vocational secondary education (SMKN); (d) 40 private vocational secondary education (SMKS); (e) 2 state Madrasah Aliyah (MAN); (f) 62 private Madrasah Aliyah (MA S). The participation of the Islamic community has important roles in secondary education services in underdeveloped regions.

The first underdeveloped region is the Sukolilo district. The participation of the Islamic community in secondary education services in this region is very dominant. Sukolilo district has six schools of secondary education, including 
(a) 1 private senior high school (SMAS); (b) 2 private vocational secondary education (SMKS); and (c) 3 private Madrasah Aliyah (MA S). There are all schools of secondary education having status as private schools. According to the interviewees from the education department in Pati Regency, those six schools are managed by the Islamic community (NU and Muhammadiyah). It means that Islamic society has dominant roles with participation rate for secondary education $100 \%$ in Sukolilo district. The existing schools of secondary education in Pati regency are shown in the following table.

Table 5.Existing of secondary education in Pati Regency

\begin{tabular}{|c|c|c|c|c|c|c|c|c|}
\hline \multirow{2}{*}{ No } & \multirow{2}{*}{ District } & \multicolumn{7}{|c|}{ Existing of secondary education } \\
\hline & & SMAN & SMAS & SMKN & SMKS & MAN & MAS & Total \\
\hline 1 & Sukolilo & & 1 & & 2 & & 3 & 6 \\
\hline 2 & Kayen & 1 & 4 & & 2 & & 5 & 12 \\
\hline 3 & Tambakromo & & & & 0 & & 1 & 1 \\
\hline 4 & Winong & & & & 1 & & 3 & 4 \\
\hline 5 & Pucakwangi & & & & 1 & & 3 & 4 \\
\hline 6 & Jaken & & & & 0 & & 1 & 1 \\
\hline 7 & Batangan & 1 & & & 1 & & 1 & 3 \\
\hline 8 & Juwana & 1 & 1 & & 3 & & 1 & 6 \\
\hline 9 & Jakenan & 1 & & & 1 & & 1 & 3 \\
\hline 10 & Pati & 3 & 6 & 2 & 8 & & 3 & 22 \\
\hline 11 & Gabus & & 1 & & 2 & & 2 & 5 \\
\hline 12 & Margorejo & & 1 & 3 & 1 & 1 & 1 & 7 \\
\hline 13 & Gembong & & 1 & & 2 & & 6 & 9 \\
\hline 14 & Tlogowungu & & & & 1 & & 4 & 5 \\
\hline 15 & Wedarijaksa & & & & 0 & & 4 & 4 \\
\hline 16 & Trangkil & & & & 0 & & 7 & 7 \\
\hline 17 & Margoyoso & & & & 5 & & 8 & 13 \\
\hline 18 & Gunungwungkal & & & & 1 & & 0 & 1 \\
\hline 19 & Cluwak & & & 1 & & & 2 & 3 \\
\hline 20 & Tayu & 1 & 1 & & 4 & 1 & 3 & 10 \\
\hline \multirow[t]{2}{*}{21} & Dukuhseti & 0 & 1 & & 5 & & 3 & 9 \\
\hline & Kabupaten Pati & 8 & 17 & 6 & 40 & 2 & 62 & 135 \\
\hline
\end{tabular}

(Source: Education department, Pati regency, 2019)

The second underdeveloped region is the Tlogowungu district. The participation of the Islamic community in secondary education services in this region is very dominant. Tlogowungu district has five schools of secondary education, including (a) 1 private vocational secondary education (SMKS); and (b) 4 private Madrasah Aliyah (MA S). Thus, there are four schools of secondary 
education having status as private schools. According to the interviewees from the education department in Pati Regency, private vocational secondary education (SMKS) has been managed by the national foundation. The Islamic community (NU) has addressed those four private Madrasah Aliyah (MA S) have been addressed by the Islamic community (NU). Therefore, Islamic society has dominant roles with participation rate for secondary education service $80 \%$ (4 of 5 schools) in Tlogowungu district.

The third underdeveloped region is the Jaken district. The participation of the Islamic community in secondary education service in this region is outstanding. Jaken district has only one school of secondary education, namely private Madrasah Aliyah (MA S). This school has been managed by the Islamic community (NU). Islamic society in the Jaken district has dominant roles with a participation rate of $100 \%$ for secondary education service.

\section{CONCLUSION}

Suburban areas or border regions tend to have slow progress in development. Among 21 districts, three under-developed regions are Sukolilo, Tlogowungu, and Jaken. Underdeveloped regions are measured by using the proportion rate of underdeveloped villages in the study area. Sukolilo district has the highest proportion of underdeveloped villages. It has 16 villages, and $4(25 \%)$ are in underdeveloped villages. Tlogowungu district became the second underdeveloped region. This district has 15 villages, and 3 of them (20\%) as underdeveloped villages. Then Jaken district became the third underdeveloped region. It has 21 villages and two villages $(9,52 \%)$ in status as a developed village.

Those under-developed regions have relatively tricky accessibility. So, the availability of education services is not as good as in the other regions. In general, the Islamic community has a significant role in education development in those regions. Firstly, the Islamic community in Sukolilo district has essential functions for education services with participation rate: (a) 30, $9 \%$ (17 of 55) for elementary school services (SD/MI); (b) 58, 33\% (7 of 12 schools) for junior high school services (SMP/MTs); and (c) $100 \%$ for secondary education services in the region. Secondly, the Islamic community in the Tlogowungu district has excellent roles for education services with participation rate: (a) 33,33\% (15 of 45) for elementary school services (SD/MI); (b) 83,33\% (10 of 12 schools) for junior high school services (SMP/MTs); and (c) $80 \%$ (4 of 5 schools) for secondary education services in the region. Thirdly, the Islamic community in Jaken district has good roles for education services with participation rate: (a) 13,33\% (4 of 30) for elementary school services (SD/MI); (b) $40 \%$ (2 of 5 schools) for junior high school services (SMP/MTs); and (c) $100 \%$ (the only one school) for secondary education service in the region. The Islamic community 
104 Suroso, The Development of Islamic Community

has significant development participation in the underdeveloped regions through education services, especially for primary education and secondary education. Therefore local government and village government should support and stimulate infrastructure development to improve accessibility and reduce disparity in development among rural areas and urban ones. 


\section{REFERENCES}

Asnuddin, Andi. "Pendekatan Partisipatif Dalam Pembangunan Proyek Infrastruktur Perdesaan di Indonesia." Smartek 8, no. 3 (2010): 170-82.

Boeren, Ellen, Ides Nicaise, and Herman Baert. "Theoretical Models of Participation in Adult Education: The Need for an Integrated Model." International Journal of Lifelong Education 29, no. 1 (2010): 45-61.

Budianta, Aziz. "Pengembangan Wilayah Perbatasan Sebagai Upaya Pemerataan Pembangunan Wilayah Di Indonesia.” SMARTek 8, no. 1 (2010): 72-82.

Firman, Arham Junaidi, and Nur Hidayat. "Strengthening Character Education Based on Golden Habits at SMP Muhammadiyah 1 Depok Yogyakarta." Cendekia: Jurnal Kependidikan Dan Kemasyarakatan 18, no. 2 (2020): 189-210.

Hamzah, Abubakar, Raja Masbar, and Sofyan Syahnur. "Economic Growth Disparity among the Regions in Aceh, Indonesia." Aceh International Journal of Social Science 2, no. 1 (2013): 21-31.

Kusumastuti, Ayu. "Modal Sosial Dan Mekanisme Adaptasi Masyarakat Pedesaan Dalam Pengelolaan Dan Pembangunan Infrastruktur." MASYARAKAT: Jurnal Sosiologi, 2015, 81-97.

Mukhibat, Muhammad Fahim Tharaba, and Munair Yusaf Abdalhafiz Salah.

"The Management of IAIN Ponorogo-Assisted Madrasas: Religious, Populist, Center of Excellence, Diversity." Cendekia: Jurnal Kependidikan Dan Kemasyarakatan 18, no. 2 (2020): 171-187.

Nina. "Rancang Bangun Peningkatan Daya Saing SDM Indonesia." Info Kajian Bappenas Volume 8, Nomor 2, 2011, 1-5.

Nurman. Strategi Pembangunan Daerah. Jakarta: PT. Raja Grafindo Persada, 2015.

Okprina, Dirka Mei. "Strategi Komunikasi Pengawas Pendidikan Menengah Di Lingkup Dinas Pendidikan Kabupaten Gresik.” Inspirasi Manajemen Pendidikan 4, no. 4 (2014): 108-21.

Permendes PDTT Nomor 2 Tahun 2016 Tentang Indeks Desa Membangun. Jakarta: Kemendes, 2016. 
"PP Nomor 13 Tahun 2015 Tentang Perubahan Kedua PP Nomor 19 Tahun 2005 Tentang Standar Nasional Pendidikan.” Jakarta: Kemendiknas, n.d.

Qerimi, Qerim, and Bruno S. Sergi. "Development and Social Development in the Global Context." International Journal of Business and Globalisation 14, no. 4 (2015): 383-407.

Rahmawati, Rahmawati. "Partisipasi Masyarakat Dalam Pelayanan Pendidikan Di SDN Cibeusi Dan SDN Jatinangor.” Fisipol Universitas Indonesia, 2011.

Razak, Andi Rosdianti. "Peran Serta Masyarakat Dalam Pembangunan." Otoritas: Jurnal Ilmu Pemerintahan 3, no. 1 (2013): 10-15.

Riyadi, Ivan. "Manajemen Pendidikan Bermuatan Antropologi, Agama Dan Sosial." Cendekia: Jurnal Kependidikan Dan Kemasyarakatan 17, no. 2 (2019): 301-316.

Ruslan, Ruslan, and Luthfiyah Luthfiyah. "Reconstruction of Educational Science With Prophetic Paradigm in Faculty of Tarbiyah at IAI Muhammadiyah Bima." Cendekia: Jurnal Kependidikan Dan Kemasyarakatan 18, no. 2 (2020): 291-311.

Saif, Muhammad Atiullah, Mohammad Maghrour Zefreh, and Adam Torok. "Public Transport Accessibility: A Literature Review." Periodica Polytechnica Transportation Engineering 47, no. 1 (2019): 36-43.

Salsabilah, Iis. "Pendidikan Karakter Islami Berbasis Nilai-Nilai Kearifan Lokal (Penelitian Di SDN 12 Ciseureuh Kahuripan Pajajaran Purwakarta).” Cendekia: Jurnal Kependidikan Dan Kemasyarakatan 17, no. 2 (2019): 269-284.

Simangunsong, Fernandes, and Imelda Hutasoit. "Empirical Study on Implementation of Village Fund for Issue of Urbanization from West Java Province to State Capital of Jakarta." International Business Management 11, no. 5 (2017): 1058-1072.

Singh, Pramod K., and Harpalsinh Chudasama. "Evaluating Poverty Alleviation Strategies in a Developing Country.” PloS One 15, no. 1 (2020): e0227176.

Supardi, U. S. "Arah Pendidikan Di Indonesia Dalam Tataran Kebijakan Dan Implementasi.” Formatif: Jurnal Ilmiah Pendidikan MIPA 2, no. 2 (2015): 111-21. 
Thoyib, Muhammad. "The Management of Multicultural Resolution on PostTransnationalism of Indonesian Islamic Education: Challenges for the Future." Cendekia: Jurnal Kependidikan Dan Kemasyarakatan 18, no. 2 (2020): 231-247.

Yusuf, Asep Warlan. "Partisipasi Masyarakat Dalam Pembangunan Kota Yang Berkelanjutan Dan Berkeadilan." Jurnal Administrasi Publik 11, no. 2 (2014): 53-68. 